\title{
DILUIÇÃO CELULAR, CARACTERÍSTICAS DO MEIO DE CULTURA E BIORREATORES DE IMERSÃO TEMPORÁRIA NA DIFERENCIAÇÃO E REGENERAÇÃO DE CÉLULAS EM SUSPENSÃO DE BANANEIRA ${ }^{1}$
}

\author{
TATIANE ROSA MONTEIRO² ${ }^{2}$ ZANDERLUCE GOMES LUIS², ELÍNEA DE OLIVEIRA FREITAS ${ }^{3}$, \\ KAZUMITSU MATSUMOTO ${ }^{4}$, JONNY EVERSON SCHERWINSKI-PEREIRA ${ }^{4}$
}

RESUMO - Altos custos de produção geralmente limitam o uso comercial da micropropagação. O uso de meios de cultura líquidos é considerado uma solução para a automação e redução de custos. Entretanto, dependendo da cultivar de bananeira, esse processo pode mostrar diferentes níveis de dificuldade, e adaptações nos protocolos são necessárias. Neste estudo, experimentos de diferenciação celular e regeneração de plantas foram desenvolvidos em células em suspensão de banana pela avaliação da densidade inicial de células, meios de cultura e sistemas de imersão temporária. Para tanto, uma sequência de três experimentos foi realizada: o primeiro avaliou os efeitos da densidade celular $(0,5 ; 1$ e $2 \mathrm{~mL})$, meios de cultura (M1: 1/2MS, 0,1 g.L. $\mathrm{L}^{-1}$ de ácido ascórbico, 0,1 g.L $\mathrm{L}^{-1}$ de L-prolina, 30 g.L $\mathrm{L}^{-1}$ de sacarose e $10 \mu \mathrm{M}$ de 2iP; M2: MS, 30 g.. $\mathrm{L}^{-1}$ de sacarose, $2,2 \mu \mathrm{M}$ de BAP e $11,4 \mu \mathrm{M}$ de AIA) e períodos de diferenciação celular (40 e 130 dias); o segundo experimento analisou o efeito do tamanho dos propágulos diferenciados em meio líquido (aprox. 2,5; 5 e 10 mm em diâmetro) na formação de embriões somáticos ou na regeneração de plantas; finalmente, um terceiro experimento avaliou o efeito de sistemas de cultivo com papel-filtro cobrindo o meio de cultura semissólido e sistemas de imersão temporários na diferenciação dos propágulos e na regeneração de plantas. Não foram observadas diferenças significativas entre os meios de diferenciação, porém as melhores diluições de células para a diferenciação foram de 1 e $2 \mathrm{~mL} / 30 \mathrm{~mL}$ de meio de cultura, enquanto diluições de $0,5 \mathrm{~mL} / 30$ $\mathrm{mL}$ de meio aumentaram a oxidação celular. A extensão do período de diferenciação de 40 para 130 dias foi importante para produzir maior número de calos/propágulos uniformes e com pelo menos de $10 \mathrm{~mm}$ de diâmetro, que puderam ser usados em sistemas de imersão temporária (biorreatores) para a diferenciação de embriões somáticos e regeneração de plantas. Considerando todos os sistemas de regeneração, verificou-se que o uso de meios de regeneração de consistência semissólida com papel-filtro na superfície do meio é o mais responsivo para a diferenciação de embriões somáticos e regeneração de plantas.

Termos para indexação: Musa spp., cultura de células, diluição celular, embriogênese somática, micropropagação.

\section{CELL DIFFERENTIATION AND PLANT REGULATORS ON BANANA}

\begin{abstract}
High production costs generally limit the commercial use of the in vitro micropropagation. The use of liquid media is considered to be the ideal solution for the automation and the production costs reduction. However, depending on the variety, this process can show different levels of difficulty and adaptations in protocols are needed. In this study experiments on cell differentiation and plant regeneration were carried out from banana cell suspension culture, by evaluating the initial cell density, the culture media and the temporary immersion systems. A sequence of three experiments was performed: the first one evaluated the effects of cell density (0.5; 1 and 2), culture media (M1: 1/2MS, 100 g.L.- ascorbic acid, $100 \mathrm{mg} . \mathrm{L}^{-1}$ L-proline, 30 g.L. - $^{-1}$ sucrose and $10 \mu \mathrm{M}$ 2iP; M2: MS, 30 g.L.-1 sucrose, 2,2 $\mu \mathrm{M}$ BA and 11,4 $\mu \mathrm{M}$ IAA) and the period of cells differentiation ( 40 and 130 days). The second one analyzed the effect of propagules size
\end{abstract}

\footnotetext{
${ }^{1}$ Trabalho Sinfruit 156 - Simpósio Internacional de Fruticultura - Avanços na Fruticultura (17 a 21 Outubro)

${ }^{2}$ Bióloga, Pós-Graduanda em Botânica - Universidade de Brasília - Instituto de Biologia, Câmpus Universitário Darcy Ribeiro, CEP 70910-900 - Brasília-DF; tatianemonteiro1@gmail.com; zanbio@hotmail.com

${ }^{3}$ Bióloga, estagiária da Embrapa Recursos Genéticos e Biotecnologia, Brasília-DF; elineaofreitas@yahoo.com.br

${ }^{4}$ Pesquisador, Embrapa Recursos Genéticos e Biotecnologia, Av. W5 Norte (final), CEP 70770-917 - Brasília-DF; kazumoto@cenargen.embrapa.br; jonny@cenargen.embrapa.br
} 
differentiated in liquid media (approx. 2.5; 5 and $10 \mathrm{~mm}$ diameter) on somatic embryo formation or plant regeneration. Finally, a third experiment analyzed the effects of culture systems with filter-paper-covered medium and temporary immersion systems, on propagules differentiation or plant regeneration. The results showed that no differences were found between both differentiation media, and the better cells densities for differentiation were $1 \mathrm{ml}$ and $2 \mathrm{~mL} / 30 \mathrm{~mL}$ medium, whereas dilutions of $2 \mathrm{~mL} / 30 \mathrm{~mL}$ medium increased cell oxidation. Extending the period in the differentiation medium from 40 to 130 days was important to produce a higher number of uniform embryogenic propagules with $10 \mathrm{~mm}$ diameter, which can be used in temporary immersion systems (bioreactors) for embryo and plant regeneration. Considering all the regeneration systems, the semi-solid regeneration medium covered by filter-paper significantly increased the somatic embryo differentiation and plants regeneration.

Index terms: Musa spp., cell culture, cellular dilution, somatic embryogenesis, micropropagation.

\section{INTRODUÇÃO}

A bananeira (Musa spp.), pertencente à família Musaceae, assume importância econômica e social em todo o mundo, sendo atualmente cultivada em diversos países (MATSUMOTO et al., 2002). Segundo Silva et al. (2006), um dos maiores problemas do cultivo da bananeira é a falta de variedades comerciais produtivas, com porte adequado e resistentes a doenças. Além disso, a cultura também apresenta problema de disponibilidade de mudas em quantidade e qualidade para uma demanda de cultivo que vem aumentando significativamente nos últimos anos (OLIVEIRA et al., 2008a; COSTA et al., 2009).

Para a multiplicação e difusão acelerada dessas mudas tem-se utilizado a cultura de tecidos de plantas, que depende muito do estabelecimento de um protocolo seguro e que propicie uma alta taxa proliferativa das bananeiras in vitro (OLIVEIRA et al., 2008b). Assim, a cultura de células e a regeneração delas via embriogênese somática, constitui-se como uma técnica de grande aplicabilidade por permitir a obtenção de grandes quantidades de mudas com qualidade e com baixo custo de produção (MORAIS-LINO et al., 2008). No entanto, vários são os fatores que devem ser controlados durante o cultivo e, entre eles, destacam-se a quantidade de inóculo a ser cultivado, além da constituição dos meios de cultura envolvidos nas diferentes etapas do processo.

Embora a estratégia de regenerar células de bananeira seja feita quase que exclusivamente pelo uso de meios semissólidos, o uso de biorreatores de imersão temporária pode ser uma excelente alternativa para aperfeiçoar e melhorar o processo. Em bananeira, são escassas as pesquisas acerca do uso de biorreatores para a clonagem de plantas a partir de células em suspensão. No entanto, o início e o aprofundamento das pesquisas poderiam propiciar aumentos significativos na produção de mudas (KOSKY et al., 2002).

Nesse sentido, o objetivo do trabalho foi ava- liar diluições celulares, as características do meio de cultura e o uso de biorreatores de imersão temporária na diferenciação e regeneração de plantas a partir de células em suspensão de bananeira.

\section{MATERIAL E MÉTODOS}

Os estudos foram conduzidos no Laboratório de Cultura de Tecidos da Embrapa Recursos Genéticos e Biotecnologia (Cenargen), Brasília-DF. No presente trabalho, utilizou-se de células em suspensão pertencente a um híbrido diploide de bananeira

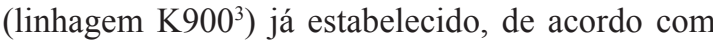
protocolo descrito por Matsumoto et al. (2010). No total, foram realizados três experimentos. A seguir, são descritas as etapas envolvidas em cada experimento:

\section{Fase de Diferenciação das células de bananeira}

$\mathrm{Na}$ fase de diferenciação celular, dois meios de cultura foram utilizados: o primeiro meio de cultura, denominado 'M1', foi constituído por $50 \%$ da formulação de sais e vitaminas do meio de MS (MURASHIGE; SKOOG, 1962), suplementado com 0,1 g.L $\mathrm{L}^{-1}$ de ácido ascórbico, 0,1 g.L $\mathrm{L}^{-1}$ de L-prolina, 30 g. $\mathrm{L}^{-1}$ de sacarose e $10 \mu \mathrm{M}$ de $2 \mathrm{iP}$ (2-isopentenil-adenina). O segundo denominado de 'M2' foi constituído pelos sais e vitaminas do meio de MS em concentração plena, $30 \mathrm{~g} . \mathrm{L}^{-1}$ de sacarose, $2,2 \mu \mathrm{M}$ de BAP (6-benzilaminopurina) e 11,4 $\mu \mathrm{M}$ de AIA (ácido indolacético). Para ambos os meios de cultura, o pH foi ajustado para 5,8 antes da autoclavagem a 121 ${ }^{\circ} \mathrm{C}$ durante 20 minutos.

Para cada meio de cultura, foram realizadas três diluições celulares de $0,5 \mathrm{~mL}, 1,0 \mathrm{~mL}$ e $2,0 \mathrm{~mL}$ do volume de células sedimentadas ( $\mathrm{SCV}$ ). Cada diluição foi inoculada em erlenmeyers contendo 30 $\mathrm{mL}$ dos meios de cultura líquido, sob agitação de $90 \mathrm{rpm}$, sendo renovados a cada duas semanas. $\mathrm{Na}$ fase de diferenciação, adotou-se um esquema fato- 
rial $2 \times 3$, com dois meios de cultura e três diluições celulares. O delineamento experimental utilizado foi inteiramente casualizado. As avaliações foram realizadas com 40 e 130 dias de cultivo, e as variáveis analisadas foram: oxidação, aspecto/cor do cultivo e diferenciação (presença de calo).

\section{Fase de Regeneração das Células de Bananeira}

Aos 40 e 130 dias nos meios de diferenciação, alíquotas de $60 \mu \mathrm{L}, 120 \mu \mathrm{L}$ e $180 \mu \mathrm{L}$ de SCV foram transferidas para meio de regeneração, constituído pelos sais de MS, acrescido de 0,1 g. $\mathrm{L}^{-1}$ de ácido ascórbico, 30 g. $\mathrm{L}^{-1}$ de sacarose, $0,79 \mu \mathrm{M}$ de BAP, $1,14 \mu \mathrm{M}$ de AIA e 2,5 g. $\mathrm{L}^{-1}$ de Phytagel.

Adotou-se um esquema fatorial $2 \times 3 \times 3$, com dois meio de cultura, três diluições da fase de diferenciação e três diluições da fase de regeneração, totalizando 18 tratamentos. O delineamento experimental foi em blocos casualizados, sendo cada diluição composta por três repetições. Cada repetição foi formada por uma placa de petri contendo cinco $\mathrm{SCV}$ por placa. Os SCVs plaqueados foram mantidos na ausência de luz. As avaliações foram feitas com 2 e 5 meses de cultivo após plaqueadas em meio de regeneração. As variáveis analisadas foram: presença de calo, regeneração e oxidação.

Para avaliar o efeito do tempo de diferenciação sobre a regeneração de células em suspensão de bananeira, células de cada diluição inicial $(0,5 ; 1,0$ e 2,0 mL) foram mantidas por até 6 meses em meio de diferenciação. Nesse estágio, calos/propágulos de diferentes tamanhos foram formados, sendo os mesmos divididos em três classes: Classe 1, apresentando diâmetro médio de $2,6 \mathrm{~mm}$, Classe 2, com média de $5,6 \mathrm{~mm}$ e Classe 3 , com calos apresentando diâmetro médio de $10,8 \mathrm{~mm}$.

Os calos diferenciados foram então plaqueados em meio semissólido de regeneração contendo ou não papel-filtro na sua superfície, de acordo com as classes de tamanhos dos calos/propágulos. Para efeitos de tratamentos, foram utilizados somente os propágulos formados nas diluições $0,5 \mathrm{~mL}$ e 1,0 $\mathrm{mL}$. A diluição 2,0 $\mathrm{mL}$ não foi utilizada por não ter apresentado a formação das três classes de calos/ propágulos.

Neste experimento, adotou-se um esquema fatorial $2 \times 2 \times 3$, com meios semissólidos de regeneração contendo ou não papel-filtro na sua superfície, duas diluições da fase de diferenciação $(0,5 \mathrm{~mL}$ e 1,0 $\mathrm{mL}$ ) e três classes de calos diferenciados (Classes 1; 2 e 3). O delineamento experimental utilizado foi inteiramente casualizado, com 12 tratamentos e 5 repetições contendo 10 calos por placa. Aos 30 e 60 dias de cultivo realizou-se avaliação do experimento. As variáveis analisadas foram: porcentagem de regeneração, calos contendo embriões e oxidação.

\section{Regeneração em Sistemas Convencionais e Bior- reatores de Imersão Temporária}

Para avaliar o sistema de regeneração em cultivos de células de bananeira, três sistemas foram testados: um sistema de regeneração em meio semissólido com papel-filtro na superfície (devido aos melhores resultados, demonstrado no experimento anterior), o biorreator R.I.T.A. (Recipiente de Imersão Temporária Automatizado) (TEISSON et al., 1995) e o Biorreator de imersão temporária - modelo da Embrapa (TEIXEIRA, 2002).

O modelo Embrapa foi constituído por dois frascos de $5 \mathrm{~L}$, com $500 \mathrm{~mL}$ de meio de cultura, conectados por tubos de silicone; um dos frascos continha o meio de cultura e, no outro, o cultivo de explantes, modelo similar ao sistema de frascos gêmeos-BIT, utilizado por Escalona et al. (1999). Nesse sistema, o ar fornecido por um compressor foi esterilizado por uma membrana de $0,44 \mu \mathrm{m}$, entrando no frasco que continha o meio de cultura e fazendo com que o líquido chegasse ao outro frasco contendo os explantes. No sistema tipo R.I.T.A., foram utilizados frascos com capacidade de 500 $\mathrm{mL}$, onde os propágulos foram inoculados, contendo $250 \mathrm{~mL}$ de meio de cultura e sendo ligados entre si através de mangueiras de silicone. Estas mangueiras foram conectadas a uma bomba de vácuo diretamente ligada a um aparelho digital reverso, que era acionado por bomba de vácuo de modo que, de tempos em tempos, o meio de cultura líquido era impulsionado para a parte superior do frasco, onde se localizavam os propágulos.

Em todos os sistemas testados, utilizaram-se calos selecionados das Classes $2(5,6 \mathrm{~mm})$ e $3(10,8$ $\mathrm{mm})$, mantendo-se a proporção de meio de cultura/ calo inoculado no sistema. Assim, em meio semissólido com papel-filtro foram colocados 10 calos/placa; 75 calos/biorreator R.I.T.A. e 150 calos/biorreator modelo Embrapa. Nos sistemas de imersão temporária, os explantes foram imersos no meio de cultura a cada 6 horas, por 1 minuto, sendo controlados por temporizadores eletrônicos.

\section{RESULTADOS E DISCUSSÃO}

Na Tabela 1, é possível observar o efeito de meios de cultura de diferenciação e o tempo de cultivo em meio de diferenciação sobre a oxidação e o aspecto/cor dos cultivos. Verificou-se que apenas o 
fator diluição afetou significativamente as variáveis estudadas. Para ambas as variáveis, a diluição celular de $2 \mathrm{~mL}$ foi a que proporcionou os melhores resultados, com células embriogênicas menos oxidadas e aspecto/cor bastante próximas ao amarelo-claro (Figura 1-B). Para a variável aspecto/cor dos cultivos (Figura 1-E), verificaram-se diferenças estatísticas entre estas diluições, sendo a menor diluição $(0,5$ $\mathrm{mL}$ ) a que apresentou os piores resultados, sugerindo que, para essa cultivar, diluições muito baixas são prejudiciais para a diferenciação dos cultivos, a primeira e uma das etapas mais importantes do processo para a regeneração celular.

Na Tabela 2, estão apresentados os resultados referentes à oxidação dos cultivos e percentagem de diferenciação/regeneração de células embriogênicas, em função dos tipos de meio de cultura, período de diferenciação celular (dias) e da diluição celular nos meios de diferenciação e regeneração. Não foi observada interação estatística significativa entre os fatores testados para nenhuma variável avaliada. Assim, para a variável oxidação dos cultivos, verificou-se que todos os tratamentos onde as células foram diferenciadas por um período de 40 dias proporcionaram os melhores resultados, independentemente do tipo de meio de cultura e da diluição utilizada na etapa de diferenciação, com exceção do período de 130 dias em meio M2 e nas diluições $0,5 \mathrm{~mL}$ e $2 \mathrm{~mL}$ em meio de diferenciação. Já quando se avaliou a diferenciação/regeneração das células, caracterizadas pela percentagem do cultivo apresentando calos em processo de regeneração ou gemas/brotos regenerados, verificou-se que, na média, os melhores resultados foram os que apresentaram diferenciação em meio M2 nas diluições de $1 \mathrm{~mL}$, quando a diferenciação das células ocorreu por 40 dias, e nas diluições de $0,5 \mathrm{~mL}$ e $1,0 \mathrm{~mL}$, quando a diferenciação ocorreu por 130 dias. Nestas diluições, as percentagens de regeneração dos explantes verificadas foram de $75 \%$, $100 \%$ e $75 \%$, respectivamente.

Os resultados para a variável regeneração, calos com embriões somáticos e oxidação dos cultivos em resposta aos fatores diluição celular em meio de diferenciação, classes de propágulos (Figura 2-A) e característica dos meios de regeneração estão apresentados na Tabela 3. Para todas as variáveis estudas, houve interação significativa dos tratamentos. Na média, os melhores resultados para regeneração foram com o uso de propágulos de classe 3 , e quando a diluição celular em meio de diferenciação foi 0,5
mL. Com relação ao uso ou não de papel-filtro sobre a superfície do meio de regeneração, não foram observadas diferenças significativas; no entanto, a percentagem de regeneração de propágulos em meio de regeneração com papel-filtro atingiu 26,0\%. Além disso, observou-se que, no meio com papel-filtro na sua superfície, de maneira geral, uma percentagem superior de propágulos nas classes 2 e 3 apresentaram maior quantidade de calos embriogênicos com embriões somáticos diferenciados (Figura 2-B), sugerindo, portanto, maior quantidade de plantas a serem regeneradas. Ainda em relação a esse meio de cultura de regeneração, embora na média a oxidação tenha sido significativamente mais elevada nessa característica de meio, não foram consideradas significativamente altas a ponto de colocar o cultivo e a regeneração de plantas em risco de tornarem-se inviáveis. Quando se avalia a taxa de calos com embriões somáticos diferenciados, verifica-se que, em ambas as classes 2 e 3 , resultados superiores foram obtidos, em especial quando se utilizou papel-filtro, observando-se percentagem de até $40 \%$.

Na Figura 3, é possível verificar o efeito de sistemas de regeneração sobre a regeneração de plantas e número de calos/propágulos com embriões somáticos diferenciados. Para a variável percentagem de regeneração de brotos, observou-se que o uso de meios semissólidos com papel-filtro na superfície e o sistema R.I.T.A. (Figura 2-E, F) não diferiram estatisticamente, com percentagens de regeneração de $12,7 \%$ e $12,6 \%$, respectivamente. Já quando se avaliou a percentagem de calos/propágulos com embriões somáticos diferenciados, verificou-se que o sistema de regeneração utilizando meio de cultura semissólido com papel-filtro foi o que proporcionou os melhores resultados, 59,3\%. Embora os resultados deste trabalho não tenham melhorado com o uso de biorreatores, Ziv (2005) descreve que diversas espécies têm sido propagadas no sistema de cultivo em biorreatores de imersão temporária, proporcionando aumento significativo em todas as fases da micropropagação e apresentando taxa de multiplicação superior quando comparada com a micropropagação convencional. O sistema de imersão amplia o contato do meio líquido com os explantes, o que proporciona maior área de absorção e, consequentemente, melhor aproveitamento da solução nutritiva (ALVARD et al., 1993; KOSKY et al., 2002; SCHERWINSKI-PEREIRA et al., 2003). 
TABELA 1 - Efeitos de meios de cultura, tempo de diferenciação e diluições celulares sobre a oxidação e aspecto de cultivos em suspensão, em um híbrido de bananeira diploide (linhagem K900³), durante a fase de diferenciação celular.

${ }^{+}$Oxidação dos cultivos $\quad{ }^{++}$Aspecto/cor dos cultivos

\begin{tabular}{cccccccc} 
& & \multicolumn{3}{c}{ Diluição $(\mathrm{mL})$} & \multicolumn{3}{c}{ Diluição $(\mathrm{mL})$} \\
\cline { 3 - 8 }${ }^{*}$ Meio de Diferenciação & $\begin{array}{c}\text { Diferenciação } \\
\text { (dias) }\end{array}$ & 0,5 & 1,0 & 2,0 & 0,5 & 1,0 & 2,0 \\
\hline \multirow{2}{*}{ M1 } & 40 & 3,0 & 3,0 & 5,0 & 4,6 & 6,0 & 8,0 \\
& 130 & 3,0 & 3,0 & 5,0 & 4,6 & 6,0 & 8,0 \\
\multirow{2}{*}{ M2 } & 40 & 3,0 & 3,6 & 5,0 & 4,0 & 7,2 & 10,0 \\
& 130 & 3,0 & 3,6 & 5,0 & 5,0 & 7,2 & 10,0 \\
\hline Média & & $3,0 \mathrm{~B}$ & $3,3 \mathrm{~B}$ & $5,0 \mathrm{~A}$ & $4,5 \mathrm{C}$ & $6,6 \mathrm{~B}$ & $9,0 \mathrm{~A}$ \\
\hline
\end{tabular}

Letras distintas minúsculas na vertical e maiúsculas na horizontal, dentro de cada variável avaliada, diferem entre si, pelo teste de Scott-Knott, a 5\% de probabilidade. ${ }^{\text {NS}}$ : não significativo; **: altamente significativo $P<0,01$.

${ }^{\dagger} \mathrm{M} 1$ : MS1/2, $100 \mathrm{mg} . \mathrm{L}^{-1}$ de ácido ascórbico, $100 \mathrm{mg} . \mathrm{L}^{-1}$ de prolina, $30 \mathrm{~g} . \mathrm{L}^{-1}$ de sacarose e $10 \mu \mathrm{M}$ de 2iP; $\mathrm{M} 2$ : MS, 30 g.L. $\mathrm{L}^{-1}$ de sacarose, $2,2 \mu \mathrm{M}$ de BAP e $11,4 \mu \mathrm{M}$ de AIA.

${ }^{+}$Notas atribuídas à oxidação dos cultivos: 1 - células bastante oxidadas; 3 - células medianamente oxidadas; 5 - Células não oxidadas.

${ }^{++}$Notas atribuídas ao aspecto/cor dos cultivos: 4 - amarelo-escuro; 6-amarelo-esverdeado; 8 - amarelo-escurecido; 10 - amarelo claro.

TABELA 2 - Efeitos de tipos de meio de cultura, tempo de diferenciação e diluições celulares sobre a oxidação e regeneração de explantes, em um híbrido de bananeira diploide (linhagem K900³).

$\begin{array}{cc}{ }^{+} \text {Oxidação dos } & { }^{++} \text {Diferenciação/Regeneração } \\ \text { cultivos } & \text { de explantes (\%) }\end{array}$

Diluição em meio de regeneração $(\mu \mathrm{L})$

\begin{tabular}{|c|c|c|c|c|c|c|c|c|c|c|}
\hline \multirow[b]{2}{*}{$\begin{array}{l}{ }^{\dagger} \text { Meio de } \\
\text { Diferen- } \\
\text { ciação }\end{array}$} & \multirow[b]{2}{*}{$\begin{array}{c}\text { Diferen- } \\
\text { ciação (dias) }\end{array}$} & \multirow[b]{2}{*}{$\begin{array}{l}\text { Diluição } \\
\text { meio de } \\
\text { diferen- } \\
\text { ciação (mL) }\end{array}$} & & \multicolumn{4}{|c|}{$(\mu \mathrm{L})$} & \multirow[b]{2}{*}{ Média } \\
\hline & & & 60 & 120 & 180 & Média & 60 & 120 & 180 & \\
\hline \multirow[t]{6}{*}{ M1 } & 40 & 0,5 & 3,5 & 5,0 & 5,0 & $4,5 \mathrm{a}$ & 50,0 & 25,0 & 75,0 & $50,0 \mathrm{~b}$ \\
\hline & & 1,0 & 4,5 & 4,5 & 4,5 & $4,5 \mathrm{a}$ & 25,0 & 0,0 & 0,0 & $8,3 \mathrm{c}$ \\
\hline & & 2,0 & 4,5 & 4,5 & 4,5 & $4,5 \mathrm{a}$ & 0,0 & 0,0 & 0,0 & $0,0 \mathrm{c}$ \\
\hline & 130 & 0,5 & 4,0 & 4,0 & 4,0 & $4,0 \mathrm{~b}$ & 0,0 & 25,0 & 25,0 & $16,7 \mathrm{c}$ \\
\hline & & 1,0 & 4,0 & 4,0 & 3,5 & $3,8 \mathrm{~b}$ & 25,0 & 0,0 & 100 & $41,7 \mathrm{~b}$ \\
\hline & & 2,0 & 4,0 & 3,5 & 3,5 & $3,7 \mathrm{~b}$ & 0,0 & 0,0 & 0,0 & $0,0 \mathrm{c}$ \\
\hline \multirow[t]{6}{*}{ M2 } & 40 & 0,5 & 5,0 & 5,0 & 5,0 & $5,0 \mathrm{a}$ & 50,0 & 50,0 & 50,0 & $50,0 \mathrm{~b}$ \\
\hline & & 1,0 & 4,5 & 4,5 & 4,5 & $4,5 \mathrm{a}$ & 75,0 & 75,0 & 75,0 & $75,0 \mathrm{a}$ \\
\hline & & 2,0 & 4,5 & 4,5 & 4,5 & $4,5 \mathrm{a}$ & 25,0 & 25,0 & 25,0 & $25,0 \mathrm{c}$ \\
\hline & 130 & 0,5 & 6,0 & 5,0 & 4,5 & $5,2 a$ & 100,0 & 100,0 & 100,0 & $100,0 \mathrm{a}$ \\
\hline & & 1,0 & 4,5 & 3,0 & 3,0 & $3,5 b$ & 100,0 & 100,0 & 25,0 & $75,0 \mathrm{a}$ \\
\hline & & 2,0 & 4,5 & 4,0 & 5,0 & $4,5 \mathrm{a}$ & 25,0 & 0,0 & 0,0 & $8,3 \mathrm{c}$ \\
\hline Média & & & $4,5 \mathrm{~A}$ & $4,3 \mathrm{~A}$ & $4,3 \mathrm{~A}$ & & $39,3 \mathrm{~A}$ & $33,3 \mathrm{~A}$ & $39,3 \mathrm{~A}$ & \\
\hline
\end{tabular}

Letras distintas minúsculas na vertical e maiúsculas na horizontal, dentro de cada variável avaliada, diferem entre si, pelo teste de Scott-Knott, a $5 \%$ de probabilidade. ${ }^{\text {Ns}}$ : não significativo; ${ }^{* *}$ : altamente significativo $P<0,01$.

${ }^{\dagger} \mathrm{M} 1$ : MS1/2, $100 \mathrm{mg} . \mathrm{L}^{-1}$ de ácido ascórbico, $100 \mathrm{mg} . \mathrm{L}^{-1}$ de prolina, $30 \mathrm{~g} . \mathrm{L}^{-1}$ de sacarose e $10 \mu \mathrm{M}$ de 2iP; M2: MS, 30 g.L ${ }^{-1}$ de sacarose, $2,2 \mu \mathrm{M}$ de BAP e $11,4 \mu \mathrm{M}$ de AIA.

${ }^{+}$Notas atribuídas à oxidação dos cultivos: 1 - células bastante oxidadas; 3 - células medianamente oxidadas; 5 - Células não oxidadas.

${ }^{++}$Diferenciação/Regeneração de explantes (\%): resultados referentes à percentagem do cultivo, apresentando calos em processo de regeneração ou gemas/brotos regenerados. 
TABELA 3 - Efeito da diluição celular, classes de propágulos e da característica do meio de cultura de regeneração, na quantidade de calos com embriões somáticos e na oxidação dos cultivos, em um híbrido de bananeira diploide (linhagem K900 $)$

\begin{tabular}{|c|c|c|c|c|c|c|c|c|c|c|}
\hline & & \multicolumn{3}{|c|}{ Regeneração (\%) } & \multicolumn{3}{|c|}{$\begin{array}{l}\text { Calos com embriões } \\
\text { somáticos }(\%)\end{array}$} & \multicolumn{3}{|c|}{ Oxidação (\%) } \\
\hline & & \multicolumn{3}{|c|}{$\begin{array}{c}\text { Característica do meio } \\
\text { de Regeneração }\end{array}$} & \multicolumn{3}{|c|}{$\begin{array}{c}\text { Característica do meio } \\
\text { de Regeneração }\end{array}$} & \multicolumn{3}{|c|}{$\begin{array}{l}\text { Característica do meio } \\
\text { de Regeneração }\end{array}$} \\
\hline $\begin{array}{l}\text { de diferen- } \\
\text { ciação } \\
(\mathrm{mL})\end{array}$ & $\begin{array}{c}\text { de } \\
\text { propágulos }\end{array}$ & $\begin{array}{l}\text { Com } \\
\text { Papel }\end{array}$ & $\begin{array}{l}\text { Sem } \\
\text { Papel }\end{array}$ & Média & $\begin{array}{l}\text { Com } \\
\text { Papel }\end{array}$ & $\begin{array}{l}\text { Sem } \\
\text { Papel }\end{array}$ & Média & $\begin{array}{l}\text { Com } \\
\text { Papel }\end{array}$ & $\begin{array}{l}\text { Sem } \\
\text { Papel }\end{array}$ & Média \\
\hline \multirow[t]{3}{*}{0,5} & 1 & $2,0 \mathrm{cA}$ & $0,0 \mathrm{Ba}$ & $1,0 \mathrm{~d}$ & $0,0 \mathrm{bA}$ & $6,0 \mathrm{bA}$ & $3,0 \mathrm{c}$ & $18,0 \mathrm{aA}$ & $8,0 \mathrm{aB}$ & $13,0 \mathrm{a}$ \\
\hline & 2 & $10,0 \mathrm{bB}$ & $18,0 \mathrm{Aa}$ & $13,1 b$ & $27,5 \mathrm{aA}$ & $20,0 \mathrm{bA}$ & $24,6 b$ & $11,2 \mathrm{bA}$ & $2,0 \mathrm{aB}$ & $7,7 b$ \\
\hline & 3 & $26,0 \mathrm{aA}$ & $12,0 \mathrm{aB}$ & $19,0 \mathrm{a}$ & $32,0 \mathrm{aA}$ & $26,0 \mathrm{aA}$ & $29,0 b$ & $0,0 \mathrm{cA}$ & $4,0 \mathrm{aA}$ & $2,0 b$ \\
\hline \multirow[t]{3}{*}{1,0} & 1 & $0,0 \mathrm{cA}$ & $0,0 \mathrm{Ba}$ & $0,0 \mathrm{~d}$ & $6,0 \mathrm{bA}$ & $8,0 \mathrm{bA}$ & $7,0 \mathrm{c}$ & $6,0 \mathrm{cA}$ & $6,0 \mathrm{aA}$ & $6,0 \mathrm{~b}$ \\
\hline & 2 & $8,0 \mathrm{bA}$ & $8,0 \mathrm{aA}$ & $8,0 \mathrm{c}$ & $40,0 \mathrm{aA}$ & $38,0 \mathrm{aA}$ & $39,0 \mathrm{a}$ & $2,0 \mathrm{cA}$ & $0,0 \mathrm{aA}$ & $1,0 \mathrm{~b}$ \\
\hline & 3 & $7,5 \mathrm{bA}$ & $2,5 \mathrm{bA}$ & $5,0 \mathrm{c}$ & $7,5 \mathrm{bB}$ & $35,0 \mathrm{aA}$ & $21,2 b$ & $22,5 \mathrm{aA}$ & $5,0 \mathrm{aB}$ & $13,7^{\mathrm{a}}$ \\
\hline Média & & $9,1,0 \mathrm{~A}$ & $6,9 \mathrm{~A}$ & & $20,0 \mathrm{~A}$ & $21,7 \mathrm{~A}$ & & $9,7 \mathrm{~A}$ & $4,1 \mathrm{~B}$ & \\
\hline
\end{tabular}

Letras distintas minúsculas na vertical e maiúsculas na horizontal, dentro de cada variável avaliada, diferem entre si, pelo teste de Scott-Knott, a 5\% de probabilidade. ${ }^{\text {NS: }}$ não significativo; **: altamente significativo $P<0,01$.

${ }^{\dagger}$ Diluições feitas em meio de diferenciação de $0,5 \mathrm{~mL}$ e $1,0 \mathrm{~mL} ;{ }^{\dagger \dagger}$ Classes de Propágulos: Classe 1 apresentando tamanho médio de 2,6 mm, Classe 2 com média de 5,6 $\mathrm{mm}$ e Classe 3 com calos apresentando tamanho médio de 10,8 $\mathrm{mm}$.
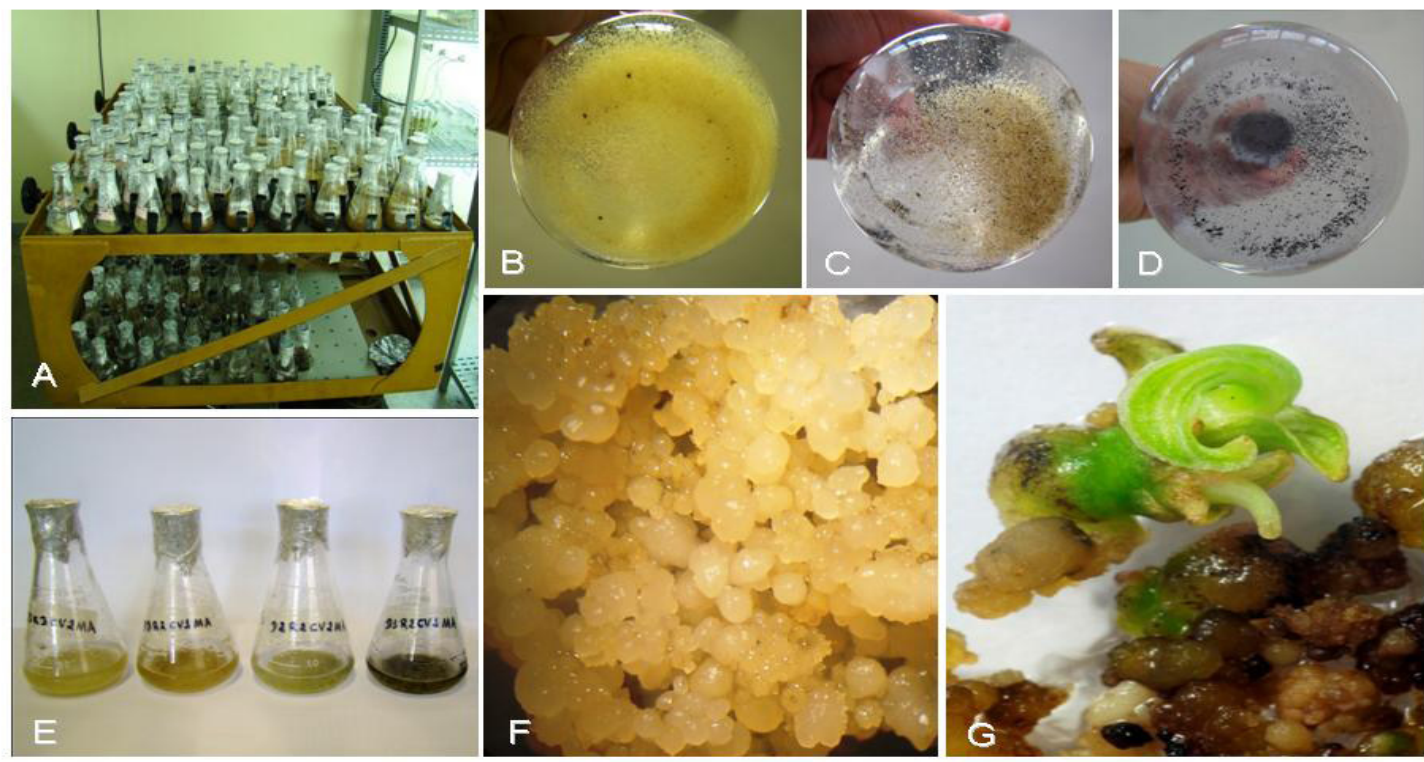

FIGURA 1 - Regeneração de mudas de bananeira a partir do cultivo de células em suspensão, em um híbrido de bananeira diploide (linhagem K900 ${ }^{3}$ ). A: aspecto da cultura de células em frascos tipo Erlenmeyers. B: aspecto da diluição celular de $2 \mathrm{~mL}$ (células não oxidadas). C: aspecto da diluição celular de $1 \mathrm{~mL}$ (células medianamente oxidadas). $\mathrm{D}$ : aspecto da diluição celular de $0,5 \mathrm{~mL}$ (células bastante oxidadas); E: Aspecto/cor do cultivo considerado durante as avaliações dos experimentos; F: Calos/propágulos com embriões somáticos diferenciados; G: Embrião somático/calo em processo de regeneração. 

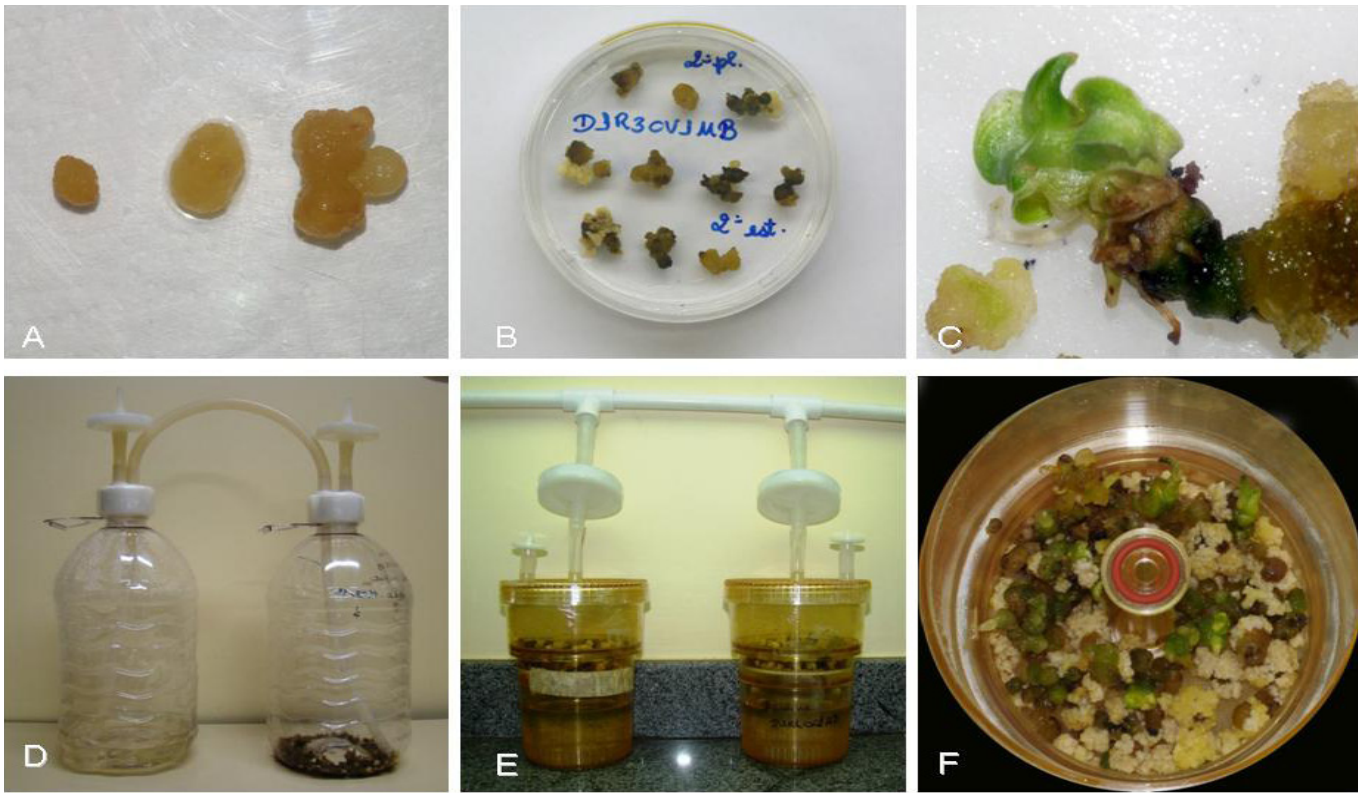

FIGURA 2 - Regeneração de mudas de bananeira a partir do cultivo de células em suspensão, em um híbrido de bananeira diploide (linhagem K9003). A: Classes de propágulos (média de 2,6 mm, 5,6 mm, $10,8 \mathrm{~mm}$, respectivamente). B: Propágulos com embriões somáticos. C: Embrião em processo de regeneração. D: Biorreator de imersão temporária modelo-Embrapa. E: Biorreator R.I.T.A. F: Aspectos dos propágulos, com embriões somáticos regenerando.

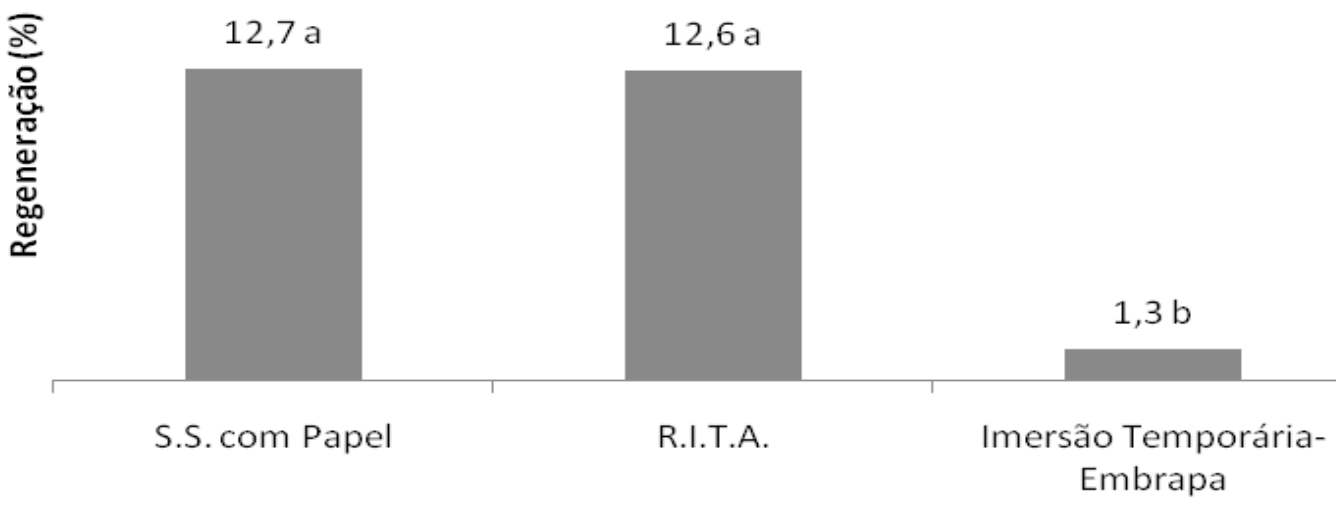

Sistemas de Regeneração 
continuação

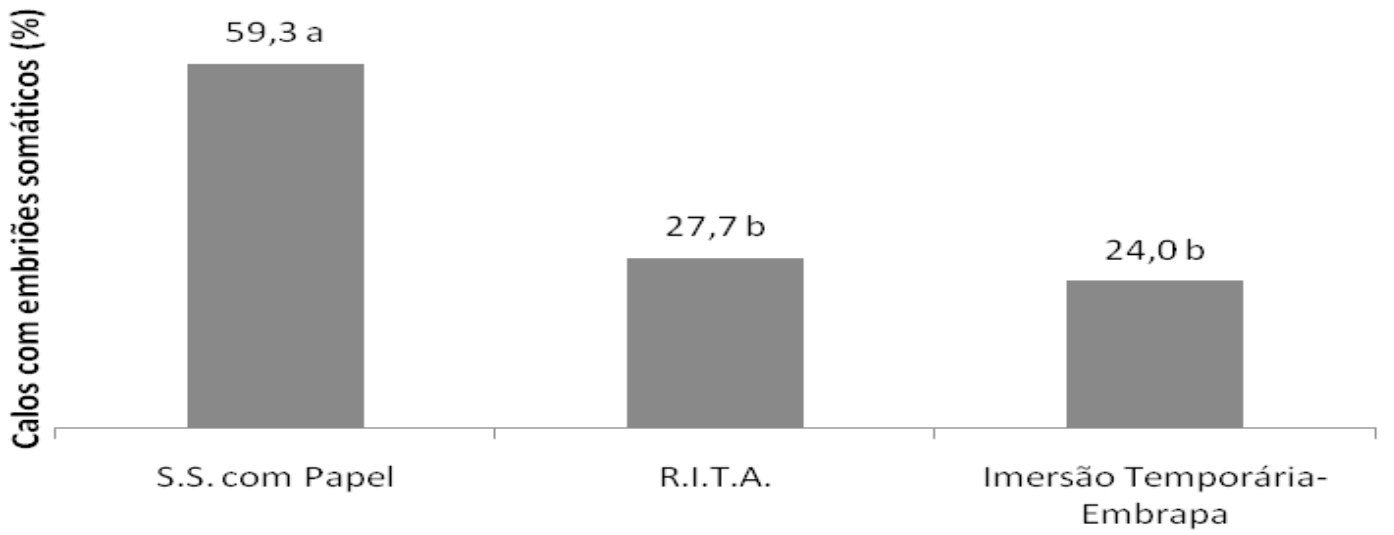

Sistemas de Regeneração

FIGURA 3 - Efeito de sistemas de cultivo (meios semissólido - SS com papel na superfície, biorreatores R.I.T.A. e de Imersão Temporária-Modelo Embrapa) na percentagem de regeneração e calos com embriões somáticos durante a etapa de regeneração de células em suspensão, em um híbrido de bananeira diploide (linhagem $\mathrm{K} 900^{3}$ ). Letras distintas após cada valor diferem entre si os sistemas de regeneração, pelo teste de Scott-Knott, a 5\% de probabilidade.

\section{CONCLUSÕES}

1. Não há diferenças significativas entre os meios de diferenciação utilizados, e as melhores diluições de células para a diferenciação são as de $1 \mathrm{~mL}$ e 2 $\mathrm{mL}$. Diluições de $0,5 \mathrm{~mL}$ aumentam a oxidação dos cultivos.

2. Em meio de regeneração, diluições de $60 ; 120$ e $180 \mu \mathrm{L}$ feitas a partir de cultivos em meios de diferenciação não influenciam nas respostas estudadas

3. Prolongar o período de diferenciação de 40 dias por até 130 dias é importante apenas para que calos se diferenciem para formar propágulos embriogênicos entre 2,5 e $10 \mathrm{~mm}$ que podem ser usados para trabalhos de regeneração, incluindo o uso de sistemas de biorreatores de imersão temporária.

4. As classes de calos/propágulos superiores a $5 \mathrm{~mm}$ de diâmetro (classes 2 e 3 ) permitem maior regeneração e diferenciação de embriões somáticos;

5. De maneira geral, o uso de meios de regeneração de consistência semissólida com papel-filtro na superfície do meio é melhor e mais responsivo para a diferenciação de embriões somáticos e regeneração de plantas.

\section{REFERÊNCIAS}

ALVARD, D.; COTE, F.; TEISSON, C. Comparison of methods of liquid medium culture for banana micropropagation. Plant Cell, Tissue and Organ Culture, Dordrecht, v.32, p.55-60, 1993.
COSTA, F.H.S.; SCHERWINSKI-PEREIRA, J.E.; PASQUAL, M.; CASTRO, E.M.; SANTOS, A.M. Perda de água e modificações anatômicas em folhas de plantas de bananeiras micropropagadas durante a aclimatização. Ciência Rural, Santa Maria, v.39, n.3, p.742-748, 2009.

ESCALONA, M.; LORENZO, J.C.; GONZALEZ, B.L.; DANQUITA, M.; GONZALES, J.L.; DESJARDINS, Y.; BORROTO, C.G. Pineapple (Ananas comosus (L.) Merr.) micropropagation in temporary immersion systems. Plant Cell Reports, Berlin, v.18, p.743-748, 1999.

KOSKY, R.G.; SILVA, M. de F.; PÉREZ, L.P.; GILLIARD, T.; MARTINEZ, F.B.; VEGA, M.R.; MILIAN, M.C.; MENDOZA, E.Q. Somatic embryogenesis of the banana hybrid cultivar FHIA-18 (AAAB) in liquid medium and scaled-up in a bioreactor. Plant Cell, Tissue and Organ Culture, Dordrecht, v.68, p.21-26, 2002.

MATSUMOTO, K.; VILARINHOS, A.D.; OKA, S. Somatic hybridization by electrofusion of banana protoplasts. Euphytica, Wageningen, v.125, p.317324, 2002.

MATSUMOTO, K.; MONTE, D.C.; TEIXEIRA, J.B.; HAICOUR, R.; DAVEY, M.R. Banana protoplasts: culture and its applicatons. Tree and Forestry Science and Biotechnology, Tokyo, v.4, n.1, p.32-38, 2010. 
MORAIS-LINO, L.S.; SANTOS-SEREJO, J.A.; SILVA, S.O.; SANTANA, J.R.F.; KOBAYASHI, A.K. Cell suspension culture and plant regeneration of a Brazilian plantain, cultivar Terra. Pesquisa Agropecuária Brasileira, Brasília, v.43, n.10, p.1325-1330, 2008.

MURASHIGE, T.; SKOOG, F. A revised medium for rapid growth and bioassays with tobacco tissue cultures. Physiologia Plantarum, Copenhagen, v.15, p. 473-497, 1962.

OLIVEIRA, J.P.; COSTA, F.H.S.; SCHERWINSKI-PEREIRA, J.E. Crescimento de mudas micropropagadas de bananeira aclimatizadas nas condições da Amazônia Sul Ocidental sob a influência de diferentes substratos e recipientes. Revista Brasileira de Fruticultura, Jaboticabal, v.30, p.459-465, 2008a.

OLIVEIRA, J.P.; COSTA, F.H.S.; SCHERWINSKI-PEREIRA, J.E. Micropropagación y estimativa de producción de mudas de bananos para la Amazonia Occidental. Pesquisa Agropecuária Brasileira, Brasília, v.43, n.10, p.1429-1432, 2008b.
SCHERWINSKI-PEREIRA, J.E.; FORTES, G.R.L. Protocolo para produção de material propagativo de batata em meio líquido. Pesquisa Agropecuária Brasileira, Brasília, v.38, n.9, p.1035-1043, 2003.

SILVA, E.A.; BOLIANI, A.C.; CORRÊA, L.S. Avaliação de cultivares de bananeira (Musa sp.) na região de Selvíria-MS. Revista Brasileira de Fruticultura, Jaboticabal, v.28, n.1, p. 101-103, 2006.

TEISSON, C.; ALVARD, C. A new concept of plant in vitro cultivation liquid medium: temporary immersion. In: TERZI, M. (Ed.). Current issues in plant molecular and celular biology. Dordrech: Kluwer Academic Publishers, 1995. p. 105-110.

TEIXEIRA, J.B. Biorreatores. Biotecnologia Ciência \& Desenvolvimento, Brasília, v.4, p.36-41, 2002. ZIV, M. Simple bioreactor for mass propagation of plant. Plant Cell, Tissue and Organ Culture, Dordrecht, v.81, n.3, p.277-285, 2005. 